\section{Assessment of the State of Competition in the Banking Market in the Russian Federation}

\author{
Anna Rabdanova \\ Master Student at the Faculty of Economics, East-Siberian State University \\ of Technology and Management, Russian Federation \\ a.rabdanova9@gmail.com
}

\section{Vera Bulatova}

Faculty of Economics, East-Siberian State University of Technology and Management, Russian Federation

bulatova_vb@mail.ru

\begin{abstract}
Competition is one of the factors directly influencing the development of the banking market, the stability of the banking system, and the monetary system as a whole. This article describes the features of banking competition, methods of analysis of banking competition, and an analysis of the current state of competition in the banking market in the Russian Federation. The analysis of banking competition in the Russian Federation was performed using the concentration ratio for the top three companies and the Herfindahl-Hirschman Index. The research concludes with an assessment of the state of competition in the banking market and identification of the barriers to entering the financial services market.
\end{abstract}

Key words: Commercial bank, bank competition, banking market, market concentration

\section{Introduction}

Competition is one of the most important factors in the development of a market economy. However, in contrast to the study of the problems of competition in the traditional markets of goods and services, the problems of banking competition in the Russian economic literature are described in less detail, particularly the following insufficiently known aspects (Korobova, 2012): problems in assessing the level of the banking competition, issues of state regulation in the banking sector, and methods for studying banking competition.

Most authors define the concept of banking competition as a dynamic process of competition between banks and other credit organizations, in which they aim to secure a strong position in the market of loans and banking services (Chumachenko \& Handruev, 2010). In other studies, banking competition is defined as a stimulating factor, forcing competitors to expand the range of banking services, improve the quality of banking products, and promptly adjust the price of these products; it encourages banks to shift to more efficient ways of functioning (Samsonova, 2007).
ORIGINAL SCIENTIFIC PAPER

RECEIVED: DECEMBER 2015

REVISED: JULY 2016

ACCEPTED: AUGUST 2016

DOI: 10.1515/ngoe-2016-0014

UDK: $336.71(470)$

JEL: G21

Citation: Rabdanova, A., \& Bulatova, V. (2016). Assessment of the State of Competition in the Banking Market in the Russian Federation. Naše gospodarstvo/Our Economy, 62(3), 13-19. DOI: 10.1515/ngoe-2016-0014

\section{NG OE}

NAŠE GOSPODARSTVO OUR ECONOMY

Vol. 62 No. 32016

pp. $13-19$ 
The following characteristic features are among the features of banking competition (Korobov, 2007):

- The subjects of banking competition are not only banks, but also non-bank financial institutions and non-financial businesses.

- The banking market consists of many different sectors, the total number of which is equal to the number of banking services (credit, cash, investment, etc.).

- The main features of banking services are intangibility, difficulty to perceive, inseparability from the source, etc.; as a result, it is more difficult for banks to promote their products.

- The banking business is characterized by high risks; therefore, banking competition requires attention from the state.

In addition, Valieva (2014) identified the following specific aspects:

- Banking markets are markets of differentiated oligopoly, providing ample opportunities for cooperation and coordination of market policies of various lending institutions; therefore, there is both individual and group interbank competition.

- As a competitive area represented by a number of sectors, in some sectors banks act as sellers placing assets while in other sectors they are buyers mobilizing resources.

- Banking services may replace each other, but do not have competitive alternatives; therefore, interbranch competition is carried out mainly by the flow of capital.

- Compared to other sectors of the market, competition between banks takes place under strict regulation by the state (licensing, monitoring, supervision).

The main purpose of this article is to assess the current state of competition in the banking market in the Russian Federation. The main goals are (i) to consider methods of analysis of banking competition, (ii) to analyze the current state of competition in the banking sector, and (iii) to identify the main barriers to entering the banking market.

\section{Method}

There are two main directions in the indirect estimation technique of banking competition: structural and non-structural methods. Structural methods include the calculation of the concentration of various indices (Herfindahl-Hirschman, etc.). Non-structural methods include the works of Panzar and Rosse (1987) as well as the model of Bresnahan-Lau, the Lerner index, and the Boone indicator.

The Panzar-Rosse approach is based on the assumptions that banks operate in a long-run equilibrium, the elasticity of demand is greater than one, cost structure is homogeneous, and the actions of banks affect the results of activities of other market participants. For equilibrium output and the equilibrium number of banks, the profit maximization problem is solved at the bank level and at the level of industry as a whole. This means that, first, $i^{\text {th }}$ bank maximizes profits at the point where the marginal product equals marginal cost. Second, the entire market will work with zero profit in equilibrium. For example, one can evaluate the following equation:

$$
\begin{aligned}
\ln P_{i t}= & \alpha_{i}+\beta_{1} \ln W_{i t}^{1}+\beta_{2} \ln W_{i t}^{2}+\beta_{3} \ln W_{i t}^{3}+ \\
& +\gamma \ln Z_{i t}+\delta D_{t}+\varepsilon_{i t}
\end{aligned}
$$

$P_{i t}-$ the ratio of gross revenues to total assets (proxy for banks' output price);

$W^{1}{ }_{i t}$ - the ratio of interest expenses to total deposits and money market funding (proxy for input price of deposits);

$W^{2}$ it - the ratio of personnel expenses to total assets (proxy for input price of labor);

$W^{3}{ }_{i t}$ - the ratio of other operating and administrative expenses to total assets (proxy for input price of equipment/fixed capital);

$Z_{i t}$ - a matrix of controls including the ratio of equity to total assets, the ratio of net loans to total assets, and the logarithm of assets;

$D_{t}-$ a matrix of year dummies;

$\alpha_{i}-$ denotes bank-level fixed effects; and

$\varepsilon_{i t}$ - the error term assumed to be normally distributed; in equation (1), it is estimated using ordinary least squares (OLS) (Anzoátegui, Martínez Pería, \& Melecky, 2010).

In this case, the H-statistic is calculated as the sum of the elasticities of revenue from cost factors: $\beta_{1}+\beta_{2}+\beta_{3}$. The estimated value of $\mathrm{H}$-statistics varies in the interval $(-\infty<H \leq 1)$. If the H-statistic is less than 0 , then it is a monopoly; if the value lies between 0 and 1 , then the market is monopolistic competition. If $\mathrm{H}=1$, then it is the perfect competition (Anzoátegui et al., 2010).

The Lerner index (Lerner, 1934) is calculated based on information on the activities of a certain bank. It determines the degree of market power as a ratio of the difference between the price set by the bank and the marginal cost to the price of the bank:

$L_{i}=\frac{\left(P_{i}-m c_{i}\right)}{P_{i}}$

$P_{i}-\quad$ price of banking outputs; and

$m c_{i}$ - the marginal cost of the $i^{\text {th }}$ bank. 
The index ranges from 0 to 1 : the higher the value, the higher the market power of the bank. If the Lerner index is equal to 0 , no firm can affect the price. Then the market has the state of perfect competition.

Marginal costs are calculated based on the trans-logarithmic function of the bank costs:

$$
\begin{aligned}
\ln C_{i t}= & \alpha_{0}+\alpha_{1} \ln Q_{i t}+\frac{\alpha_{2}}{2}\left(\ln Q_{i t}\right)^{2}+\sum_{j} \beta_{j} \ln w_{j i t}+ \\
& +\frac{1}{2} \sum_{j} \sum_{k} \beta_{j k} \ln w_{j i t} \ln w_{k i t}+ \\
& +\sum_{j} \gamma_{j} \ln Q_{i t} \ln w_{j i t}+D_{i t}+\varepsilon_{i t}
\end{aligned}
$$

$C_{i t}-$ total costs of the $i^{\text {th }}$ bank in period $t$;

$Q_{i t}-$ bank product;

$w_{j i t}$ - price of $j$-factor;

$D_{i t}$ - matrix of dummy variables corresponding to the period; and

$\varepsilon_{i t}-\quad$ random error.

Thereafter, the marginal cost $m c_{\mathrm{i}}$ of the $i^{\text {th }}$ bank in period $t$ will be calculated according to the formula:

$m c_{i t}=\frac{\partial C_{i t}}{\partial Q_{i t}}=\left(\alpha_{1}+\alpha_{2} \ln Q_{i t}+\sum_{j} \gamma_{j} \ln w_{j i t}\right) \frac{C_{i t}}{Q_{i t}}$

The important point is to determine a bank product. In empirical studies, bank assets are considered a bank product (Anzoátegui et al., 2010). The total amount of loans issued by the bank and the total amount of deposits accepted can also be used as a bank product.

In this paper, the Herfindahl-Hirschman index has been used to assess banking competition. This method was selected for the initial study of competition in the banking sector of the Russian Federation.

For the analysis of bank competition, it is necessary to determine the volume of the banking market and to assess the level of concentration of the market. The volume of the financial market can be defined as the sum of the volume (turn) of the financial services provided by all financial institutions for a certain period:

$V_{f r}=\sum_{i=1}^{n} V_{i}$

\footnotetext{
$V_{f r}-\quad$ market volume;

$V_{i}-\quad$ the volume of the financial services of a financial organization; and

$i=1,2, \ldots, n-$ the number of financial organizations operating in the financial services market.
}

In order to determine the market's financial resources, the market volume can be defined as the amount of assets (fixed capital) of financial organizations operating in a certain market.

This figure is more applicable to the market with the same institutional structure of financial institutions. For example, this figure applies to the market of banking services, represented exclusively by credit institutions, and to the market of insurance services if the majority of existing insurers can be compared by the amount of assets (fixed capital).

As a rule, the following indicators are used to assess the level of market concentration:

a) Market concentration ratio $\left(C R_{n}\right)$, which is calculated as a percentage of the volume of financial services provided by a certain number of the largest participants in the financial services market to the total market volume:

$C R_{n}=\frac{\left(V_{1}+V_{2}+\cdots+V_{n}\right)}{V} \times 100 \%$

$V_{1}+V_{2}+\ldots+V_{n}-$ the volume of financial services of the largest participants in the financial services market.

b) Index of market concentration, or Herfindahl-Hirschman index (HHI), which is calculated by squaring the percentage of the market of each participant and summing the results:

$H H I=D_{1}^{2}+D_{2}^{2}+\cdots+D_{m}^{2}$

$D_{i}-\quad$ percentage of the market of each participant; and $i=1,2, \ldots, m$.

If data of major participants in the market of financial services are available but the necessary information on all financial institutions is not, the estimation of market concentration is performed using the concentration ratio. Concentration ratios are usually determined for three $\left(C R_{3}\right)$, four $\left(C R_{4}\right)$, six $\left(C R_{6}\right)$, eight $\left(C R_{8}\right)$, and more members (depending on the total number of participants in the market). In order to estimate the level of concentration of the studied market of financial services, it is recommended to determine the concentration ratio of the three largest market participants and the HHI.

The market can be considered as highly, moderately, or lowly concentrated depending on the values of the concentration indicators. There are several interpretations of the 
HHI thresholds. According to the U.S. Department of Justice and the Federal Trade Commission (1997), markets are considered to be unconcentrated if $\mathrm{HHI}<1000$, moderately concentrated if $1000<\mathrm{HHI}<1800$ and $\Delta \mathrm{HHI}>100$, and highly concentrated if $\mathrm{HHI}>1800$ and $\Delta \mathrm{HHI}>50$. However according to the EU Horizontal Merger Guidelines of 2004, markets are considered to be unconcentrated if $\mathrm{HHI}<1000$, moderately concentrated if $1000<\mathrm{HHI}<2000$ with $\Delta \mathrm{HHI}$ $<250$, and highly concentrated if HHI $>2000$ and $\Delta \mathrm{HHI}<$ 150 (“Guidelines on the assessment," 2004)

The HHI threshold used in the Russian Federation corresponds to the threshold of the European Union. The Order of Federal Antimonopoly Service of Russian Federation from 28.04.2010 N 220 (2015) "On approval of the analysis of the state of competition in the product market" established the procedure for determining the market concentration.

Highly concentrated markets:

$70 \%<=C R_{3}<=100 \%$;

$2000<=H H I<=10000$;

Moderately concentrated markets:

$45 \%<=C R_{3}<70 \%$;

$1000<=H H I<2000$;

Lowly concentrated markets:

$C R_{3}<45 \%$;

$H H I<1000$.

If necessary, the proportion of a particular financial institution in the market can be calculated. A financial organization's share of the financial resources in the studied market of financial services can be determined as a percentage of total assets (equity capital) of financial organizations to the financial resources volume of the studied market:

$D_{i(a)}=\frac{V_{i(a)}}{V_{f r(a)}}$

\section{Results}

Data on the assets of Russian banks having the right to conduct banking operations in the last three years were obtained to calculate the above-mentioned parameters. Results are presented in Table 1.

Table 1 shows that the market of banking services is increasing every year, despite the fact that the number of credit institutions is decreasing every year. The largest bank in Russia, Sberbank, consistently accounts for about 30\% of the total market.
Concentration ratio fluctuated and increased in 2015 to $47 \%$, which corresponds to a moderately concentrated market. The HHI until 2011 was less than 1000, which corresponds to lowly concentrated markets. However, after 2011 the value exceeded 1000. Thus, it can be concluded that, at the moment, the market can be classified as moderately concentrated.

To consider separate markets in which commercial banks operate, Table 2 provides an analysis of the market of deposits and Table 3, the loans market.

Table 2 shows that, since 2009, the number of credit institutions has decreased. However, the volume of deposits in banks has increased every year. Sberbank's share in the total market fell from 52\% in 2008 to $46 \%$ in 2015.

The concentration ratio fluctuated slightly, but its value was always higher than $50 \%$, which corresponds to a moderately concentrated market. On the other hand, the HHI exceeded 2000 during the period, which corresponds to a highly concentrated market. This can be explained by the fact that Sberbank holds a leading position in the Russian banking sector, while the proportion of even the second and third largest banks in the total amount of the market are negligible.

According to the data in Table 3, the volume of loans issued by banks also increased every year. In contrast to the deposits market, the share of the largest bank was about $30 \%$ for the entire period. The concentration factor gradually increased, and its value almost always corresponded to a moderately concentrated market. The HHI value for the entire period also corresponded to a moderately concentrated market. Thus, it can be concluded that the banking market in the Russian Federation is moderately concentrated. At the same time, it is dominated by one large bank with state participation.

Depending on the level of concentration of the financial services market, antitrust authorities' actions are differentiated in relation to various markets and operating financial institutions. Thus, the following measures are suitable for moderately concentrated markets:

- $\quad$ regarding the dynamics of concentration, if the process of concentration increases it is necessary to move toward the measures provided for highly concentrated markets;

- control over the market behavior of financial institutions, occupying a dominant position in the financial services market;

- actions to reduce the barriers to enter the financial services market to create equal opportunities for all players;

- prevention and suppression of the abuse of a dominant position by a financial institution; and 
Table 1. Analysis of the Russian Federation's Banking Market: Assets

\begin{tabular}{|c|c|c|c|c|c|c|c|c|}
\hline Index & 2008 & 2009 & 2010 & 2011 & 2012 & 2013 & 2014 & 2015 \\
\hline Number of operating credit institutions & 954 & 1015 & 1000 & 965 & 939 & 902 & 821 & 716 \\
\hline Market volume, bln. Rub. & 26742.94 & 28416.44 & 33040.86 & 40791.68 & 48461.79 & 56265.06 & 76349.68 & 80743.33 \\
\hline Sberbank's share, \% & 25.56 & 26.93 & 27.68 & 26.91 & 29.06 & 29.73 & 29.26 & 29.16 \\
\hline $\begin{array}{l}\text { Concentration ratio for the top three } \\
\text { companies }\left(C R_{3}\right)\end{array}$ & 41.85 & 42.63 & 41.89 & 43.25 & 43.82 & 45.55 & 46.39 & 47.23 \\
\hline Herfindahl-Hirschman Index $(H H I)$ & 852.68 & 914.89 & 932.26 & 930.58 & 1020.51 & 1078.43 & 1089.09 & 1102.55 \\
\hline
\end{tabular}

Source: Informational Agency Banki.ru, ltd. (2016c)

Table 2. Analysis of the Deposit Market in the Russian Federation

\begin{tabular}{|c|c|c|c|c|c|c|c|c|}
\hline Index & 2008 & 2009 & 2010 & 2011 & 2012 & 2013 & 2014 & 2015 \\
\hline Number of operating credit institutions & 954 & 1015 & 1000 & 965 & 939 & 902 & 821 & 716 \\
\hline Market volume, bln. Rub. & 5878.37 & 7465.24 & 9803.01 & 11871.29 & 14250.91 & 16957.44 & 18549.25 & 23015.66 \\
\hline Sberbank's share, \% & 52.12 & 49.58 & 47.97 & 46.60 & 45.68 & 46.68 & 45.00 & 46.37 \\
\hline $\begin{array}{l}\text { Concentration ratio for the top three } \\
\text { companies }\left(C R_{3}\right)\end{array}$ & 59.64 & 57.57 & 56.50 & 55.67 & 54.67 & 56.77 & 55.76 & 57.83 \\
\hline Herfindahl-Hirschman Index $(H H I)$ & 2771.47 & 2522.82 & 2371.99 & 2249.24 & 2164.73 & 2271.66 & 2127.55 & 2266.63 \\
\hline
\end{tabular}

Source:Informational Agency Banki.ru, ltd. (2016a)

Table 3. Analysis of the Loans Market in the Russian Federation

\begin{tabular}{|c|c|c|c|c|c|c|c|c|}
\hline Index & 2008 & 2009 & 2010 & 2011 & 2012 & 2013 & 2014 & 2015 \\
\hline Number of operating credit institutions & 954 & 1015 & 1000 & 965 & 939 & 902 & 821 & 716 \\
\hline Market volume, bln. Rub. & 16550.50 & 16308.65 & 18558.66 & 23935.26 & 28618.75 & 33581.71 & 42126.88 & 45298.35 \\
\hline Sberbank's share, \% & 31.30 & 32.29 & 31.49 & 32.75 & 33.36 & 33.37 & 35.30 & 33.97 \\
\hline $\begin{array}{l}\text { Concentration ratio for the top three } \\
\text { companies }\left(C R_{3}\right)\end{array}$ & 43.80 & 45.54 & 44.28 & 46.59 & 46.49 & 47.24 & 49.86 & 51.15 \\
\hline Herfindahl-Hirschman Index $(H H I)$ & 1129.48 & 1202.43 & 1144.45 & 1235.19 & 1264.01 & 1279.29 & 1424.76 & 1388.47 \\
\hline
\end{tabular}

Source:Informational Agency Banki.ru, ltd. (2016b)

- approval of mergers, accession of financial institutions, and acquisitions of blocking and controlling blocks of shares (stakes) in the authorized capital of financial institutions, provided that the market potential will not increase or exceed the average values for the moderately concentrated markets.

The following main barriers to entering the banking market can be identified:

- Significant initial capital investments with a long payback period. Thus, the minimum authorized capital for newly registered bank is 300 million rubles.

- Legal restrictions of banking activities. Restrictions, such as obtaining a license to operate, are necessary in order to complicate market entry for weak banking structures, thereby excluding the possibility that competition becomes destructive.
- Costs of access to the necessary resources and intellectual property rights, advertising costs, costs of obtaining information. The entry of new unknown banks can be difficult because customers prefer well-known banks with a long history. As a result, costs to reorient customers are quite high.

- Advantages of economic entities operating on the studied market to potential market participants, particularly the advantages of unit costs and demand for goods and advantages of long-term contracts with clients.

\section{Conclusion}

This article analyzed bank competition in the Russian Federation, calculating the market volume on assets, volumes 
of deposit and loan markets, share of the largest party, the concentration ratio for the top three companies, and the HHI. According to the results, it can be concluded that the Russian banking services market is related to the market of underdeveloped competition. There are barriers to entering the financial services market that impede the rapid entry of new banks. In turn, the operating credit institutions are subjected to strong control by the state, which is manifested in the audit of the Central Bank for compliance with the applicable regulations. The number of banks on the market has declined, as in recent years the Central Bank has revoked licenses due to the tightening of regulations. The modern unstable economic situation, antitrust regulation activities, and the strengthening of globalization processes in the international economic system have had a significant impact on competition in the banking market.

\section{References}

1. Anzoátegui, D., Martínez Pería, M. S., \& Melecky, M. (2010). Banking sector competition in Russia. Policy Research Working Paper WPS5449, The World Bank. http://dx.doi.org/10.1596/1813-9450-5449

2. Chumachenko, A. A., \& Handruev, A. A. (2010). Competition in the banking sector: trends, issues, forecasts. Bankovskoe delo, $11,6-12$.

3. Guidelines on the assessment of horizontal mergers under the Council Regulation on the control of concentrations between undertakings. (2004). Official Journal C 031, 0005-0018.

4. Korobov, Y. I. (2007). Banking competition: the role, specifics and prospects of development. Sovremennaya konkurenciya, 1,87-93.

5. Korobova, G. G. (2012). Banking culture as a factor in the development of banking competition. Bankovskie uslugi, 2,12-23.

6. Lerner, A. P. (1934). The concept of monopoly and the measurement of monopoly power. The Review of Economic Studies, 1(3), 157-175. http://dx.doi.org/10.2307/2967480

7. Order of Federal Antimonopoly Service of Russian Federation from 28.04.2010 N 220 (2015, January 30). On approval of the analysis of the state of competition in the product market.

8. Panzar, J. C., \& Rosse, J. N. (1987). Testing for monopoly equilibrium. The Journal of Industrial Economics, 35(4), 443-456. http://dx.doi.org/10.2307/2098582

9. Informational Agency Banki.ru, ltd. (2016a). Rating of Russian banks in the deposit market. Retrieved from http://www.banki.ru/banks/ratings/?SEARCH_NAME=\&SEARCH_REGN=\&search\%5Btype\%5D=name\&sort_param=rating \&sort_order=ASC \&PROPERTY_ID=60\&REGION_ID=0 $\&$ date1=2009-01-01 \&date2=2008-12-01\&IS_SHOW_GROUP=0\&IS_SHOW_LIABILITIES=0\#search_label

10. Informational Agency Banki.ru, ltd. (2016b). Rating of Russian banks in the loans market. Retrieved from http://www.banki.ru/banks/ratings/?SEARCH_NAME=\&SEARCH_REGN=\&search\%5Btype\%5D=name\&sort_param=rating \&sort_order=ASC\&PROPERTY ID=40\&REGION_ID=0 \& date1=2009-01-01\&date2=2008-12-01\&IS_SHOW_GROUP=0\&IS_SHOW_LIABILITIES=0\#search_label

11. Informational Agency Banki.ru, ltd. (2016c). Rating of Russian banks. Retrieved from http://www.banki.ru/banks/ratings/?SEARCH_NAME=\&SEARCH_REGN=\&search\%5Btype\%5D=name\&sort_param=rating \&sort_order=ASC \&PROPERTY_ID=10\&REGION_ID=0 \& date1=2013-01-01\&date2=2012-12-01\&IS_SHOW_GROUP=0\&IS_SHOW_LIABILITIES=0\#search_label

12. Samsonova, E. K. (2007). Formation and development of competitive environment in the banking market in Russia: problems and prospects. Finansy i kredit, 29, $2-7$.

13. U.S. Department of Justice and the Federal Trade Commission. (1997). Horizontal Merger Guidelines. Washington: U.S. Government Printing Office.

14. Valieva, E. N. (2014). Competition on the market of financial services: theory and practice. Finansy $i$ kredit, 40(616), 2-7.

\section{Authors}

Anna Rabdanova is currently a master's degree student in the Finance and Credit Department at East-Siberian State University of Technology and Management's Faculty of Economics. She has a bachelor's degree in economics. Her research focuses primarily on bank lending, banking competition, and bank management.

Vera Bulatova, Ph.D. in economics, is an assistant professor in the Finance and Credit Department, Faculty of Economics, East-Siberian State University of Technology and Management. She teaches courses on financial and monetary and credit methods in economic management, analysis of financial risks, and investment analysis. Her field research includes regional policy, investment policy, and bankruptcy. 


\section{Presoja stanja konkurence na bančnem trgu v Ruski federaciji}

\section{Izvleček}

Konkurenca je eden od dejavnikov, ki neposredno vplivajo na razvoj bančnega trga ter na stabilnost bančnega in monetarnega sistema kot celote. $V$ prispevku so opisane značilnosti tržne konkurence, metode analize konkurence med bankami ter analiza sedanjega stanja konkurence na bančnem trgu Ruske federacije. Analizirana sta konkurenca med bankami v Ruski federaciji, pri čemer smo izhajali iz določitve razmerja v koncentraciji za tri najvišje uvrščena podjetja, in Herfindahl-Hirshmanov indeks. Zaključek raziskave vključuje presojo stanja konkurence na bančnem trgu in identificiranje ovir pri vključevanju na trg finančnih storitev.

Ključne besede: poslovna banka, konkurenca med bankami, bančni trg, tržna koncentracija 